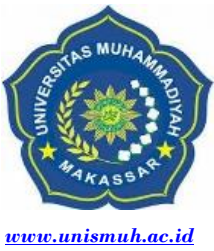

www.unismuh.ac.id
Jurnal Equilibrium Pendidikan Sosiologi

Vol V Desember No. 22017

\title{
Analisis Persepsi Masyarakat Kawasan Adat Amma Toa Kajang Terhadap Muhammadiyah
}

\author{
Hasmiati \\ IAIM Sinjai
}

miaelbugis@gmail.com

\begin{abstract}
This research uses field research (field research) with qualitative method. The subject of this research is with Indigenous Stakeholder, Village Apparatus, Community Leader, Religious Leader, Youth Leader, Academician and Kader Muhammadiyah who are domiciled in Adat area. Data collection by observation method, data writing method, technical data, data presentation and data recall. Triangulation is done to explain the validity of the data by using source and method triangulation. The results showed that the interaction of cadres and indigenous peoples is a positive and harmonious relationship, primary and secondary social contact because both parties are mutually understanding, profitable and long-standing cooperation. Conflicts that occur between the cadres and indigenous communities are still entangled lightly and only temporary. Indigenous people's perception of Amma Toa to Muhammadiyah is positive and negative, but still tend to Negative. It is caused by perceptions based on experience, efaluatif, contextual, selective and care. The perception of Amma Toa to Muahammadiyah is caused by internal and external factors. Factors factors that make individual perceptions different from each other and will be oriented to the individual in perceiving an object.
\end{abstract}

Keywords: Pasang Rikajang, Gender, Social Culture

Abstrak. Penelitian ini menggunakan penelitian lapangan (field research) dengan metode kualitatif. Subjek penelitian ini adalah dengan informan Pemangku Adat, Aparat Desa, Tokoh Masyarakat, Tokoh Agama, Tokoh Pemuda, Akademisi dan Kader Muhammadiyah yang berdomisili kawasan Adat. Pengumpulan data dilakukan dengan metode observasi, metode wawancara dan metode dokumentasi, Teknik yang digunakan dalam analisis data adalah pengumpulan data, reduksi data, penyajian data dan penarikan kesimpulan. Trianggulasi yang dilakukan untuk menjelaskan keabsahan data dengan menggunakan trianggulasi sumber dan metode. Hasil penelitian menunjukkan bahwa, Interaksi kader dan masyarakat adat merupakan interaksi positif dan harmonis, kontak sosial secara primer maupun sekunder karena kedua pihak terdapat saling pengertian, kerjasama yang menguntungkan dan sudah berlangsung lama. Konflik yang terjadi antara kader dan masyarakat adat yaitu masih berupa konflik ringan dan hanya bersifat sementara. Persepsi masyarakat adat Amma Toa terhadap Muhammadiyah bersifat Positif dan Negatif, tapi masih cenderung Negatif. Hal itu disebabkan oleh persepsi berdasarkan pengalaman, efaluatif, kontekstual, selektif dan bersifat dugaan. Persepsi masyarakat adat Amma Toa terhadap Muahammadiyah dipengaruhi oleh faktor internal dan eksternal. Sehingga faktor-faktor tersebut menjadikan persepsi individu berbeda satu sama lain dan akan berpengaruh pada individu dalam mempersepsi suatu objek.

Kata Kunci: Pasang Rikajang, Gender, Sosial Budaya. 


\section{PENDAHULUAN}

Kawasan adat Amma Toa berada di kabupaten Bulukumba sekitar $190 \mathrm{~km}$ dari Makassar ibu kota Sulawesi Selatan ini dipimpin oleh seorang ketua terpilih dengan sebutan Amma Toa. Amma Toa bertanggung jawab penuh menjaga adat dan tradisi bisa berjalan selaras dengan alam. Selain itu Amma Toa juga bertindak sebagai pemimpin spiritual tertinggi. Tana Toa yang berarti tanah yang tertua. Nama ini berdasarkan kepercayan masyarakat Kajang yang mendiaminya, yang yakin Tana Toa adalah daerah yang pertama kali diciptakan oleh Tuhan di muka bumi ini. Masyarakat Tana Toa percaya bahwa bumi ini adalah warisan nenek moyang yang berkualitas dan seimbang. Oleh karena itu, anak cucunya harus mendapatkan warisan tersebut dengan kualitas yang sama persis. Kepercayaan inilah yang membuat lingkungan di Tana Toa terjaga kelestariannya.

Meskipun Islam diakui masyarakat Amma Toa sebagai agama satu-satunya dalam kawasan adat, akan tetapi dalam kehidupan beragama mereka masih mencampurbaurkan dengan ajaranajaran leluhur (kepercayaan) yang masih mereka pegang teguh. Kawasan adat Kajang memiliki keunikan tersendiri dalam hal menata kehidupan dan hidup sederhana karena setiap langkah aktivitas memiliki tujuan tersendiri serta memiliki landasan ideologi sebagai paham hidup, yakni pasang ri kajang atau tradisi lisan sebagai nasihat untuk berbuat yang bermakna holistik dan sakral. Tradisi pasang berupa ungkan lisan yang tidak tertulis masa dahulu.

Sebagai gerakan pembaharuan, Muhammadiyah yang melaksanakan misi dakwah dan tajdid untuk mewujudkan masyarakat Islam yang sebenar-benarnya. Bagi Muhammadiyah Islam merupakan nilai utama sebagai fondasi dan pusat inspirasi yang menyatu dalam seluruh denyut-nadi gerakan. Muhammadiyah berkeyakinan bahwa Islam sebagai risalah yang dibawa oleh para Nabi sejak awal kenabian hingga Nabi akhir zaman Nabi Muhammad S.A.W. adalah agama Allah yang lengkap dan sempurna. Islam selain mengandung ajaran berupa perintah-perintah dan larangan- larangan tetapi juga irsyadat untuk keselamatan hidup umat manusia di dunia dan akhirat(PP. Muhammadiyah, 2010: 21). Muhammadiyah sebagai organisasi Islam besar di Indonesia, tidak dapat dilepaskan dari sejarah pembangunan bangsa Indonesia. Dalam perjalanannya organisasi yang berdiri pada tahun 1912 ini, telah memberikan banyak kontribusi bagi bangsa Indonesia, khususnya dibidang kegamaan, sosial dan pendidikan. (PP. Muhammadiyah, 2003:119)

Kawasan adat Amma Toa bukanlah hal baru bagi Muhammadiyah, karena Muhammadiyah lahir di tengah tengah kebudayaan sinkretik Jawa yang kental. Islam merupakan agama yang mengandung nilai-nilai kemajuan, yang kehadirannya diyakini mampu membawa rahmat bagi kemajuan, kehidupan manusia sepanjang masa, karena itu Muhammadiyah berkomitmen untuk terus mengembangkan pandangan dan misi Islam yang berkemajuan dan berkeadaban sebagaimana spirit awal kelahirannya. Keberhasilan Muhammadiyah melintasi zaman memasuki abad kedua adalah bukti sejarah keberhasilan K.H. Ahmad Dahlan meletakkan dasar-dasar keislaman yang kuat kepada kader-kader militan berkualitas yang mampu menangkap spirit kiyai menterjemahkan Islam dalam tataran praktis dalam kehidupan bermasyarakat.

Kawasan adat Amma Toa merupakan kawasan yang sarat akan ritual memiliki berbagai macam adat upacara yang diperuntukkan para leluhurnya dan menutup diri dari modernisasi, Sehingga hal ini menarik untuk dikaji, peneliti ingin mengetahui lebih dalam bagaimana persepsi masyarakat kawasan adat Amma Toa terhadap Muhammadiyah, dan bagaimana interaksi sosial kader Muhammadiyah yang berdomisili di kawasan adat.Adapun rumusan masalah dalam penelitian ini yaitu; Bagaimana Interaksi Sosial Kader Muhammadiyah terhadap Masyarakat Kawasan Adat Ammatoa Kajang, dan Bagaimana Persepsi Masyarakat Kawasan Adat Amma toa Kajang Terhadap Muhammadiyah, Penelitian ini menggunakan penelitian lapangan (field research) dengan metode kualitatif, Untuk mendapatkan data primer dalam penelitian ini menggunakan 
wawancara mendalam dan observasi dengan beberapa informan kunci (Pemangku Adat, Aparat Desa, Tokoh Masyarakat, Tokoh Agama, Tokoh Pemuda, dan Kader Muhammadiyah yang berdomisili kawasan Adat) dan untuk pengembangan pemahaman digunakan metode focus group discussion (FGD). Penelitian ini Dibiayai Oleh Hibah Riset muhammadiyah 2017, Majelis DIKTILITBANG PP Muhammadiyah

\section{METODE PENELITIAN}

\section{PEMBAHASAN}

\section{Letak Serta Kondisi Fisik}

Letak geografis Desa Tana Toa antara $5^{\circ}$ 20? LS dan $120^{\circ} 22$ ? BT. Desa Tana Toa merupakan salah satu dari sembilan belas desa/kelurahan di Kecamatan Kajang, Kabupaten Bulukumba Sulawesi Selatan. Kecamatan Kajang memiliki luas wilayah 129,06 km terpilah ke dalam dua kelurahan yakni kelurahan Tana Jaya yang juga sebagai ibu kota kecamatan dan kelurahan Laikang, serta tujuh belas desa (Bonto Biraeng, Bonto Rannu, Lembang, Lembang Lohe, Possi Tana, Lembanna, Tambangan, Sangkala, Bonto Baji, Pattiroang, Sapanang, Batu Nilamung, Tana Toa, Maleleng, Mattoanging, Lolisang dan Pantama).

Khusus Desa Tana Toa memiliki luas wilayah 5,25 kilometer persegi. Ibukota desa ini terletak di Dusun Balagana. Karena sebagian besar wilayah Kecamatan Kajang merupakan kawasan adat sehingga secara umum sering diidentikkan semua wilayah ini sebagai kawasan Tana Toa. Wilayah Desa Tana Toa sendiri terbagi kedalam delapan dusun yaitu Dusun Sobbu, Dusun Benteng, Dusun Pangi, Dusun Tombolo, Dusun Lurayya, Dusun Balambina, Dusun Jannaya dan Dusun Balagana. Dusun Jannaya dan Dusun Balagana merupakan dusun peralihan) karena selain menganut tata nilai yang bersumber dari ajaran pasang, juga menganut tata nilai yang tidak bersumber dari ajaran pasang. Dusun ini terletak di wilayah Ipantarang Embaya, yaitu wilayah di luar kawasan Ammatoa.

\section{Bentuk Kegiatan}

Jenis-jenis Pesta adat ataupun acara yang masih terjaga sampai sekarang dan dilaksanakan oleh masyarakat Adat Amma Toa Kajang, berdasarkan penelusuran dan hasil penelitian yang dilakukan peneliti meliputi: (a) A'tompolo, Pesta ini dengan sama dengan aqiqah yang biasa dilaksanakan umat Islam sebagai rasa syukur atas kelahiran seorang bayi dalam sebuah keluarga. Hari pelaksanaan pun sama yakni pada hari ketujuh setelah bayi dilahirkan atau berdasarkan kesiapan kemampuan orang tua. (b) Akkalomba, merupakan pesta memohon keselamatan agar anak-anak terhindar dari penyakit. (c) Akkatere, Pesta ini mirip dengan acara pemotongan rambut bagi anak bayi yang baru dilahirkan dikalangan suku Bugis Makassar. Pesta Akkatere sarat dengan makna dan simbol utamanya peralatan-peralatan dan bahanbahan yang dipakai pada saat Pesta. Akkatere menjadi lebih penting apabila dihadiri oleh ke 26 dewan adat Ammatoa. Dan masyarakat mengumpapamakan orang yang mampu melaksanakan kattere bagaikan orang sudah sederajat Muslim yang telah naik haji ke Baitullah. (d) Passalangngan, yaitu Pesta khitanan atau yang biasa juga disebut Passunnakkang (pengislaman). (e) Pa'buntinganatau pesta perkawinan/ pernikahan. Dengan beberapa tahapan. Yang pertama a?duta dan attarima duta, A?nikkah, Nideppo, A? lampa Basa, Nipasiampi, a?lampa bangngi na allampa Bisang. (f) Tilapo, A'dampo, Lajo-lajo atau Pa'dangangang, yaitu Pesta kematian. Pesta ini mememerlukan biaya yang paling besar dibanding Pesta-Pesta lainnya dan prosesi acaranya berlangsung selama 100 hari. (g) Nai' ri Bola, yaitu Pesta yang dilaksanakan sehubungan mulainya ditempati rumah yang baru. Biasanya seorang Uragi atau seorang ahli pertukangan memimpin Pesta ini. (h) Andingingi, yaitu upacara ritual untuk menyiram bumi dengan percikan air yang sudah dimantra oleh pemimpin adat. Dengan harapan kehidupan dunia adapat dijalani dengan sejuk dan selamat.bebas dari marabahaya seperti kemerau panjang, panas suhu bumi. (i) Attuanamatang, yaitu Pesta untuk pemujaan roh-roh leluhur. (j) Doangang, yaitu 
Pesta untuk memohon keselamatan. (k) Sumaja, yaitu pesta nazar kecil dan dalam skala besar disebut Taraba'goro, atau biasa masyarakat yang bersangkutan mendatangi tempat yang dianggap sakrai untuk melakukan ritual. (I) Akkaharu, yaitu Pesta yang berhubungan dengan dunia pertanian terutama tanaman padi dan jagung, mulai dari pemilihan bibit, penanaman dan penyimpanan. Kondisi dianggap khusus bila terjadi serangan hama dan penyakit pada tanaman, apalagi jika hamanya adalah hama tikus. (m) Tompang, yaitu Pesta yang berhubungan dengan dunia peternakan. Pesta ini dilaksanakan untuk mengusir penyakit yang menyerang hewan ternak. (n) Angnganro ri Sapo, yaitu Pesta yang dilakukan di rumah (sapo), skala acara ini cukup besar, dilaksanakan bila ada musibah di bidang pertanian atau panen berhasil. Biasanya Pesta ini dilaksanakan di Possi Tana Desa Mattuanging. (o) Pangnganroang, yaitu Pesta untuk memanjatkan doa dan memohon kepada Tuhan untuk diberi keselamatan dan terhindar dari wabah penyakit. Selain itu Pesta ini biasa juga dilakukan untuk memohon turunnya hujan. (p)

Paruntu'Panganro Sibatu Lino,yaitu Pesta ritual untuk keselamatan alam semesta dengan segala isinya. Pesta ini terdiri dari 3 tahapan yaitu: (Paruntu'Panganro Cucu Bola: Pesta ini dilaksanakan setiap tahun dan diikuti oleh seluruh masyarakat Ilalang Embayya. Paruntu' Panganro Pa'rasangang: Pesta ini dilaksanakan setiap sepuluh tahun sekali dan diikuti oleh masyarakat Ilalang Embayya dan Ipantarang Embayya. Paruntu' Panganro Sibatu Lino: Pesta ini dilaksanakan setiap seratus tahun sekali dan diikuti oleh seluruh masyarakat baik Ilalang Embayya maupun Ipantarang Embayya. (q) Allisa' Ere Tallasa: yaitu Pesta pada waktu seorang anak pertama kali menginjakkan kakinya di tanah. Pesta ini dilaksanakan untuk memohon berkah agar langkah anak-anak mereka di kemudian hari menjadi langkah-langkah yang berguna bagi keluarga dan masyarakat. (r) Appanganro Akkatto: yaitu Pesta ritual yang dilakukan. Ammatoa untuk menyambut yang kuasa memeberi berkah padi Sangiasserri dari peraduannya menuju ke istananya yaitu di lumbung penyimpanan (Para Bola). Suatu tempat penyimpanan pangan di atas Flafon rumah yang disediakan.

\section{Interaksi Sosial Kader Muhammadiyah terhadap Masyarakat Adat Amma Toa Kajang}

Kajian interaksi sosial bermula dari pandangan Max Weber yang dikenal dengan kajian tindakan sosial. Tindakan sosial Sesuai dengan pemahaman yang disampaikan oleh Max Weber bahwa; "Tidak semua tindakan manusia dapat dianggap sebagai tindakan sosial. Suatu tindakana hanya dapat disebut tindakan sosial apabila tindakan tersebut dilakukan dengan mempertimbangkan prilaku orang lain dan beriorentasi pada prilaku orang lain" .Tindakan sosial adalah prilaku manusia yang mempunyai makna subjektif bagi pelakunya. Terjadinya Tindakan manusia yang mempunyai makna subjektif dan sering terjadi ditempat lain dan mempengaruhi orang lain secara sosiologis dinamakan dengan Interaksi sosial (Weberdalam Kamanto,2000;12)

Sebagai makhluk sosial manusia tidak dapat hidup tanpa bantuan dari orang lain. Adanya rasa memerlukan bantuan dari orang lain, maka manusia akan melakukan kontak ataupun komunikasi satu sama lainnya, dari itu terjadilah suatu interaksi sosial dimana dalam interaksi tersebut terjadi suatu kontak sosial baik secara langsung maupun tidak langsung, dengan interaksi tersebut semua manusia hidup sebagai makhluk sosial. Dalam pembahasan ini akan dikemukakan mengenai interaksi sosial yang terjadi antara kader dan masyarakat adat, baik interaksi yang menunjukkan hubungan yang harmoni ke arah positif maupun interaksi yang menunjukkan konflik atau pertentangan. Dalam proses sosial, baru dapat dikatakan terjadi interaksi sosial, apabila telah memenuhi persyaratan sebagai aspek kehidupan bersama, yaitu kontak sosial dan komunikasi sosial. (Abdul syani. 2007:154).

Kontak sosial adalah hubungan antara satu orang atau lebih, melalui percakapan dengan saling mengerti tentang maksuddantujuan masing-masing dalam masyarakat. Kontak sosial dapat terjadi secara langsung ataupun tidak langsung 
antara satu pihak dengan pihak yang lainnya, begitupun dengan komunikasi sosial yang merupakan syarat daripada proses sosial. Persyaratan tersebut dapat kita lihat dalam interaksi sosial kader Muhammadiyah terhadap masyarakat adat Amma Toa Kajang. Berdasarkan hasil observasi peneliti, kader Muhammadiyah yang bermukim di Desa Tana Toa mereka aktif dalam interkasi dengan masyarakat adat Amma Toa.

Kader Muhammadiyah menyadari betul bagaimana bermasyarakat atau berinteraksi dengan baik, hal inilah kemudian yang dijaga oleh kader yang bermukim di kawasan adat Amma Toa, agar hidup berdampingan dan saling menghargai, satu sama lain.

Kader dan masyarakat adat terjadi interaksi sosial, dengan adanya kontak sosial dan komunikasi sosial sebagai syarat adanya interaksi sosial. Kontak sosial yang terjadi adalah bersifat positif dan kontak sosial secara primer maupun sekunder karena kedua pihak terdapat saling pengertian, kerjasama yang menguntungkan dan sudah berlangsung lama. Menurut teori interaksionisme simbolik yang dikemukakan oleh Georg Simmel menyatakan bahwa terbentuknya masyarakat (kelompok atau asosiasi) adalah akibat adanya interaksi timbal balik, melalui proses sosiasi (proses dimana masyarakat itu terjadi) inilah individu saling berhubungan dan saling mempengaruhi satu sama lain. Sehingga tanpa adanya anggota- anggotanya atau individu itu sendiri masyarakat tidak akan pernah terbentuk. Berdasarkan teori tersebut bahwa suatu masyarakat akan terbentuk bila adanya individu saling berhubungan dan saling mempengaruhi satu sama lain. Inti dari teori interaksionisme simbolik adalah suatu aktivitas yang merupakan ciri khas manusia, yaitu komunikasi atau pertukaran simbol yang diberi makna. Hal ini bisa kita lihat pada interaksi sosial kader Muhammadiyah yang berinteraksi antara masyarakat adat Amma Toa.

Setiap individiu atau kelompok pasti memiliki perbedaan baik berupa bentuk fisik, kebudayaan, pola piker dan sebagainya. Perbedaan-perbedaan tersebut yang sering memicu terjadinya sebuah pertentangan atau konflik antar individu ataupun kelompok. Ada beberapa penyebab terjadinya suatu konflik, antara lain: (Soerjono:99) (a) Perbedaan antar individu, perbedaan pendirian dan perasaan dapat juga menimbulkan konflik atau pertentangan. (b) Perbedaan kebudayaan, perbedaan kepribadian juga tergantung pada pola kebudayaan yang melatarbelakangi pembentukan serta perkembangan kepribadian itu sendiri. Sedikit banyaknya indivdu akan terpengaruh oleh polapikir dan pendirian dari kelompok dimana dia berada. Hal ini pun dapat menyebabkan konflik antar kelompok. (c) Perbedaan kepentingan, wujud kepentingan dapat berbagai macam. Kepentingan ini dapat berupa kepentingan ekonomi, politik, dan lain sebagainya. (d) Perubahan sosial. Perubahan sosial yang cepat untuk sementara waktu akan mengubah nilai-nilai yang ada dalam masyarakat. Perubahan inipun dapat menimbulkan konflik bagi mereka yang berbeda pendirian.

Banyaknya perbedaan diantara kader dan masyarat adat itulah menyebabakan timbulkan sebuah konflik. konflik yang terjadi dalam sebuah kelompok dapat berupa konflik ringan ataupun konflik yang berskala berat. Konflik antar kader dan masyarakat adat terjadi dikarenakan beberapahal, antara lain perbedaan pendapat ketika musyawarah, kepercayaan yang berbeda diantara kader dan masyarakat adat.

Konflik yang terjadi antara kader dan masyarakat adat yaitu berupa konflik ringan yang hanya bersifat sementara. Berdasrkan teori interaksi sosial, dari segi subjeknya maka Interaksi sosial antara kader dan masyarakat adat, yaitu antara orang perorangan dan antara orang dengan sekelompoknya, dengan cara interaksi langsung dan interaksi simbolik. Dan jika dilihat dari bentuknya, maka interaksi yang terjadi antara kader dan masyarakat berupa kerjasama.

Kerjasama yang terjalin antara kader dan masyarakat adat dalam partisipasi kader dan masyarakat pada kegiatan Desa, sebagai khatib, pesta adat, pembina TK TPA, majelis taklim, dan berpartisipasi pada kegiatan masyarakat adat lainnya. Berhasil atau tidaknya, interaksi sosial yang terjalin antara kader dan masyarakat adat, terdapat 
faktor yang mempengaruhi diantaranya: Situasi sosial, Kekuasaan norma-norma kelompok, adanya tujuan kepribadian yang dimiliki masingmasing individu sehingga berpengaruh terhadap perilakunya, setiap individu berinteraksi sesuai dengan kedudukan dan kondisinya yang bersifat sementara, adanya penafsiran situasi (Santoso, $2004: 12)$.

Dalam hubungan-hubungan sosial yang lebih luas setiap anggota Muhammadiyah baik sebagai individu, keluarga, maupun jama'ah (warga) dan jam'iyah (organisasi) haruslah menunjukkan sikapsikap sosial yang didasarkan atas prinsip menjunjung-tinggi nilai kehormatan manusia, memupuk rasa persaudaraan dan kesatuan kemanusiaan, mewujudkan kerjasama umat manusia menuju masyarakat sejahtera lahir dan batin, memupuk jiwa toleransi, menghormati kebebasan orang lain, menegakkan budi baik, menegakkan amanat dan keadilan, perlakuan yang sama, menepati janji, menanamkan kasih sayang dan mencegah kerusakan, menjadikan masyarakat menjadi masyarakat yang shalih dan utama, bertanggung jawab atas baik dan buruknya masyarakat dengan melakukan amar ma'ruf dan nahi munkar, berusaha untuk menyatu dan berguna/ bermanfaat bagi masyarakat, memakmurkan masjid, menghormati dan mengasihi antara yang tua dan yang muda, tidak merendahkan sesama, tidak berprasangka buruk kepada sesama, peduli kepada orang miskin dan yatim, tidak mengambil hak orang lain, berlomba dalam kebaikan, dan hubungan- hubungan sosial lainnya yang bersifat ishlah menuju terwujudnya masyarakat Islam yang sebenar-benarnya.

Untuk memaksimalkan potensi kader dalam mensyiaarkan Islam demi mencapai tujuan Muhammadiyah, maka seorang kader harus bermanfaat bagi masyarakat. Kader harus pandai menempatkan dirinya, terutama di tengah masyarakat yang masih menjaga tradisi para leluhurnya dan tertutup dari modernisasi. Spirit K.H. Ahmad Dahlan dalam mendirikan Muhammadiyah menjadikan motivasi bagi kader Muhammadiyah dalam mensyiarkan Islam. Dimanapun seorang kader berada maka dia senantiasa bermanfaat bagi kemaslahatan ummat dalam ber amar ma?ruf nahi munkar mampu menunjukan integritas dan kompetensi dalam keberagamaan, akademis dan Intelektual, serta sosial kemanusiaan. Seperti dalam kitab suci Qs: Ali-Imran ayat 104 yang mengilhami pendiri Muhammadiyah, (dan hendaklah ada di antara kamu segolongan umat yang menyeru kepada kebajikan, menyuruh kepada yang ma'ruf dan mencegah dari yang munkar, merekalah orangorang yang beruntung).

Inilah yang menjadi sumber kekuatan seorang kader dalam menjalani aktifitas kesehariannya ditengah masyarakat adat Amma Toa. Berdasarkan hasil Observasi dan wawancara peneliti, bahwa Interaksi kader dan masyarakat adat merupakan interaksi positif dan harmonis, dan bentuk konfliknya bersifat ringan.

\section{Analisis Persepsi Masyarakat Adat Amma Toa Kajang terhadap Muhammadiyah}

Persepsi adalah inti komunikasi, sedangkan penafsiran (interpretasi) adalah inti persepsi, yang identik dengan penyandian-balik (decoding) dalam proses komunikasi. Persepsilah yang menentukan kita memilih suatu pesan dan mengabaikan pesan lain. (Mulyana, 2000) Persepsi adalah pengalaman tentang objek, peristiwa, atau hubungan-hubungan yang diperoleh dengan menyimpulkan informasidan menafsirkan pesan (Rakhmat 2001). Persepsi ialah memberikan makna pada stimuli indrawi (sensory stimuli).

Rudolph F memberikan pengertian, "persepsi adalah proses menafsirkan informasi inderawi". (dikutip dari SurantoAw,2010, 197). 'persepsi merupakan suatu proses menginterpretasikan atau menafsir informasi yang diperoleh melalui system alat indera manusia? (Suharman, 2005, 23). Menurutnya ada tiga aspek di dalam persepsi yang dianggap relevan dengan kognisi manusia, yaitu pencatatan indera, pengenalan pola, dan perhatian. Dari penjelasan di atas dapat ditarik suatu kesamaan pendapat bahwa persepsi merupakan suatu proses yang dimulai dari penglihatan hingga terbentuk tanggapan yang terjadi dalam diri individu sehingga individu sadarakan segala sesuatu 
dalam lingkungannya melalui indera-indera yang dimilikinya.

Persepsi merupakan suatu proses yang didahului oleh penginderaan. Penginderaan adalah merupakan suatu proses diterimanya stimulus oleh individu melalui alat penerima yaitu alat indera. Namun proses tersebut tidak berhenti di situ saja, pada umumnya stimulus tersebut diteruskan oleh syaraf ke otak sebagai pusat susunan syaraf, dan proses selanjutnya merupakan proses persepsi. Karena itu proses persepsi tidak lepas dari proses penginderaan, dan proses penginderaan merupakan proses yang mendahului terjadinya persepsi. (Walgito, 2010:99).

Dari data yang diperoleh dan dari hasil pengamatan penulis terkait persepsi masyarakat adat Amma Toa Kajang terhadap Muhammadiyah, kemudian membandingkannya dengan teori yang telah dikemukakan pada bab II. berdasarkan hasil penelitian di lapangan masyarakat adat Amma Toa memiliki persepsi yang berbeda-beda terhadap Muhammadiyah.

Bahwa setiap orang mempunyai kecenderungan dalam melihat benda yang sama dengan cara yang berbeda-beda. Perbedaan tersebut bias dipengaruhi oleh banyak faktor, diantaranya adalah pengetahuan, pengalaman dan sudut pandangnya. Persepsi juga bertautan dengan cara pandang seseorang terhadap suatu objek tertentu dengan cara yang berbeda-beda dengan menggunakan alati ndera yang dimiliki, kemudian berusaha untuk menafsirkannya. Persepsi baik positif maupun negative ibarat file yang sudah tersimpan rapi di dalam alam pikiran bawah sadar kita. File itu akan segera muncul ketika ada stimulus yang memicunya, ada kejadian yang membukanya. Setiap orang mempunyai pendapat (persepsi) yang berbeda-beda terhadap obyek rangsang yang sama. Perbedaan persepsi antara individu dengan individu lainya terhadap obyek tertentu, tergantung pada kemampuan seseorang dalam menanggapi, mengorganisir, dan menafsirkan informasi tersebut.

Proses persepsi merupakan stimulus yang diinderakan oleh individu yang diorganisasikan, kemudian diinterpretasikan sehingga individu yang bersangkutan menyadari dan mengerti mengenai stimulus yang diinderanya.

\section{Proses Terjadinya Persepsi Masyarakat}

a. Sensasi (penginderaan)

Semua indra yang ada pada manusia mempunyai andil bagi berlangsungnya sebuah komunikasi. Seperti halnya penglihatan menyampaikan pesan non verbal ke otak untuk diinterpretasikan, pendengaran juga menyampaikan pesan verbal ke otak untuk ditafsirkan, begitupun sentuhan dan pengecapan memainkan peran penting dalam komunikasi, seperti lewat bau parfum dan sampah yang menyengat. Maka dalam banyak kasus, rangsangan yang menarik perhatian kita cenderung dianggap lebih penting daripada yang tidak menarik perhatian kita. Rangsangan seperti itu cenderung dianggap penyebab kejadian-kejadian berikutnya. Ini juga berlaku untuk manusia: orang yang paling kita perhatikan cenderung dianggap paling berpengaruh.

b. Interpretasi

Interpretasi adalah tahap terpenting dalam persepsi. Sebenarnya kita tidak dapat menginterpretasikan makna setiap obyek secara langsung, melainkan menginterpretasi makna informasi yang kita percayai mewakili obyek tersebut. Jadi pengetahuan yang kita proleh melalui persepsi bukan pengetahuan mengenai obyek yang sebenarnya, melainkan pengetahuan mengenai bagaimana bagaimana tampaknya obyek tersebut. (Nurdin, 2013, 160). Dari persepsi masyarakat terhadap Muhammadiyah, kemudian melahirkan interprestasi. Interpretasi merupakan suatu aspek kognitif dari persepsi yang sangat penting yaitu proses memberikan arti kepada stimulus yang diterimanya. Proses interpretasi tersebut bergantung pada cara pendalaman, motivasi, dan kepribadian seseorang. 
Jenis dan Faktor Yang Melatarbelakangi Persepsi Masyarakat Adat Terhadap Muhammadiyah

a. Jenis - Jenis Persepsi

Persepsi terbagi dua yaitupersepsi terhadap objek (lingkungan fisik dan persepsi terhadap manusia). Persepsi terhadap manusia lebih sulit dan kompleks, karena manusia bersifat dinamis. Perbedaan kedua tersebut yaitu: (1) Persepsi terhadap objek melalui lambang - lambang fisik, sedangkan persepsi terhadap manusia melalui lambang-lambangverbaldannon verbal.Orang lebih aktif dari pada kebanyakan objek dan lebih sulit diramalkan. (2) Persepsi terhadap objek menanggapi sifat-sifat luar, sedangkan persepsi terhadap orang menanggapi sifat-sifat luar dan dalam (perasaan, motif, harapan dan sebagainya). (Mulyana 2000, 171)

Rahmat (2005) menyebutkan persepsi dibagi menjadi dua bentuk yaitu positif dan negatif, apabila objek yang dipersepsi sesuai dengan penghayatan dan dapat diterima secara rasional dan emosional maka manusia akan mempersepsikan positif atau cenderung menyukai dan menanggapi sesuai dengan objek yang dipersepsikan. Apabila tidak sesuai dengan penghayatan maka persepsinya negatif atau cenderung menjauhi, menolak dan menanggapinya secara berlawanan terhadap objek persepsi tersebut. Robbins (2002) menambahkan bahwa persepsi positif merupakan penilaian individu terhadap suatu objek atau informasi dengan pandangan yang positif atau sesuai dengan yang diharapkan dari objek yang dipersepsikan atau dari aturan yang ada. Sedangkan, persepsi negatif merupakan persepsi individu terhadap objek atau informasi tertentu dengan pandangan yang negatif, berlawanan dengan yang diharapkan dari objek yang dipersepsikan atau dari aturan yang ada.

Penyebab munculnya persepsi negatif seseorang dapat muncul karena adanya ketidakpuasan individu terhadap objek yang menjadi sumber persepsinya, adanya ketidaktahuan individu serta tidak adanya pengalaman inidvidu terhadap objek yang dipersepsikan dan sebaliknya, penyebab munculnya persepsi positif seseorang karena adanya kepuasan individu terhadap objek yang menjadi sumber persepsinya, adanya pengetahuan individu, serta adanya pengalaman individu terhadap objek yang dipersepsikan.

Kehidupan sosial budaya yang berbeda dengan masyarakat pada ummunya dan ritual adat yang terjaga berdasarkan pasang ri kajang, hal ini pula menjadi salah satu faktor yang menyebabkan persepsi masyarakat masih cenderung negatif terhadap Muhammadiyah.

Persepsi sosial adalah sebagai berikut, proses menangkap arti objek-objek sosial dan kejadiankejadian yang kita alami dalam lingkungan kita. Setiap orang memiliki gambaran yang berbeda mengenai realitas disekelilingnya. Beberapa prinsip mengenai persepsi sosial sebagaimana dikemukan oleh Mulyana (2000:75) yaitu persepsi berdasarkan pengalaman, bersifat dugaan, persepsi bersifat evaluatif, bersifat selektif dan bersifat kontekstual.

Berdasarkan hasil pengamatan dan wawancara selama penelitian, maka persepsi masyarakat adat Tana Toa terhadap Muhammadiyah yaitu sebagai berikut:

1. Persepsi berdasarkan pengalaman yaitu persepsi manusia terhadap seseorang, objek atau kejadian dan reaksi mereka terhadap hal-hal itu berdasarkan pengalaman dan pembelajaran masa lalu mereka berkaitan dengan orang, objek atau kejadian serupa.

2. Persepsi bersifat dugaan. Persepsi bersifat dugaan terjadi oleh karena data yang kita peroleh mengenai objek lewat penginderaan tidak pernah lengkap.

3. Persepsi bersifat evaluatif. Persepsi bersifat evaluatif maksudnya adalah kadangkala orang menafsirkan pesan sebagai suatu proses kebenaran, akan tetapi terkadang alat indera dan persepsi kita menipu kita, sehingga kita juga ragu seberapa dekat persepsi kita dengan realitas yang sebenarnya.

\section{Faktor yang Mempengaruhi Persepsi}

Menurut Miftah Toha (2003: 154), faktorfaktor yang mempengaruhi persepsi seseorang adalah sebagai berikut: (a) Faktor internal: perasaan, sikap dan kepribadian individu, 
prasangka, keinginan atau harapan, perhatian (fokus), proses belajar, keadaan fisik, gangguan kejiwaan, nilai dan kebutuhan juga minat, dan motivasi. (b) Faktor eksternal: latar belakang keluarga, informasi yang diperoleh, pengetahuan dan kebutuhan sekitar, intensitas, ukuran, keberlawanan, pengulangan gerak, hal-hal baru dan familiar atau ketidak asingan suatu objek.

Berdasarkan hasil pengamatan dan wawancara yang dilakukan oleh peneliti, bahwa persepsi masyarakat adat Amma Toa terhadap Muahammadiyah dipengaruhi oleh faktor internal dan eksternal. Sehingga faktor-faktor tersebut menjadikan persepsi individu berbeda satu sama lain dan akan berpengaruh pada individu dalam mempersepsi suatu objek, stimulus, meskipun objek tersebut benar-benar sama. Perspsi seseorang atau kelompok dapat jauh berbeda dengan persepsi orang atau kelompok lain sekalipun situasinya sama. Perbedaan persepsi dapat ditelusuri pada adanya perbedaanperbedaan individu, perbedaan perbedaan dalam kepribadian, perbedaan dalam sikap atau perbedaan dalam motivasi. Pada dasarnya proses terbentuknya persepsi ini terjadi dalam diri seseorang, namun persepsi juga dipengaruhi oleh pengalaman, proses belajar, dan pengetahuannya.

\section{KESMPULAN}

Berdasarkan hasil pembahasan penelitian dalam penelitian ini, maka dapat diambil kesimpulan sebagai berikut:

1. Keberadaan Pengurus ranting Muhammadiyah di Desa Tana Towa merupakan awal pencerahan bagi generasi masyarakat adat Kajang sebagai agen perubahan sosial dalam menyongsong masa depan umat Islam. Pimpinan ranting Muhammadiyah Tanah Towa belum diketahui oleh masyarakat adat secara keseluruhan, akan tetapi mereka berjalan saat ini dalam melakukan pengajian dan kajian Islam di Masjid Al-Tajdid tanah Towa yang diikuti beberapa orang Jamaah masyarakat setempat. Baik berupa Remaja maupun orang Dewasa. Pengajian yang dilakukan pengurus ranting Muhammadiyah Tanah Toa dilaksanakan bukan atas nama
Muhammadiyah secara organisasi serta kurangnya fasilitas dan alokasi dana dalam mensyiarkan Islam lewat Muhammadiyah.

2. Interaksi kader dan masyarakat adat merupakan interaksi positif dan harmonis, kontak sosial secara primer maupun sekunder karena kedua pihak terdapat saling pengertian, kerjasama yang menguntungkan dan sudah berlangsung lama. Konflik yang terjadi antara kader dan masyarakat adat yaitu masih berupa konflik ringan dan hanya bersifat sementara

3. Persepsi masyarakat adat Amma Toa terhadap Muhammadiyah bersifat Positif dan Negatif, tapi masih cenderung Negatif. Hal itu disebabkan oleh persepsi berdasarkanpengalaman, efaluatif, kontekstual, selektif dan bersifat dugaan. Persepsi masyarakat adat Amma Toa terhadap Muahammadiyah dipengaruhi oleh faktor internal dan eksternal. Sehingga faktor-faktor tersebut menjadikan persepsi individu berbeda satu sama lain dan akan berpengaruh pada individu dalam mempersepsi suatu objek.

\section{DAFTAR PUSTAKA}

[1] Abdul Syani. (2007). Sosiologi, Skematika, Teori, Dan Terapan. Jakarta: PT.Bumi Aksara.

[2] Aminah. PH, Sitti Dra. (1989).Nilai-Nilai Luhur Budaya Spiritual Masyarakat Ammatoa Kajang. Ujung Pandang: Kanwil Depdikbud Propinsi Sulawesi Selatan.

[3] Bimo Walgito. (2007). Psikologi Kelompok. Yogyakarta: ANDI

[4] Jalaludin Rakhmat. (2000). Psikologi Komunikasi. (Bandung: PT. Remaja Rosdakarya.

[5] Koentjaraningrat. (2009) Pengantar Ilmu Antropologi. Jakarta: Rineka Cipta.

[6] Mahmud, M. Dimyanti. (1990).Psikologi Suatu Pengantar. Jakarta: Depdikbud.

[7] Mudji sutrisno \& Hendar putranto. (2005). Teori-teori kebudayaan. Yogyakarta: Kanisius.

[8] Mulyanan Deddy. (2000). IImu Komunikasi Suatu Pengantar. Bandung: PT.Remaja Rosdakarya.

[9] PP. Muhammadiyah. (2010).Berita Resmi Muhammadiyah. Yogyakarta: Surya Sarana Grafika.

[10] PP. Muhammadiyah. (2001). Pedoman Hidup Islami Warga Muhammadiyah. Yogyakarta: Suara Muhammadiyah.

[11] Suharman. (2005). Psikologi Kognitif. Surabaya: Srikandi. 
[12] Suranto.Aw.(2010). Komunikasi Sosial Budaya. Yogyakarta: Graha IImu.

[13] Soekanto, Soerjono. (2006). Sosiologi Suatu Pengantar. Jakarta: PT. Raja Grafindo Persada

[14] Sunarto Kamanto. (2004). Pengantar Sosiologi (edisi ketiga). Jakarta: Lembaga Penerbit Fakultas Ekonomi, Universitas Indonesia.

[1] Miftah Toha. (2003). Perilaku Organisasi Konsep Dasar dan Aplikasinya. Jakarta: Grafindo Persada.

[15] Ali Nurdin.,dkk., (2013). Pengantar Ilmu komunikasi, Cet; I. Surabaya: IAIN SA Press.

[16] Skripsi: Ahman Yulisar, B. N. (2014). Peran pemerintah daerah dalam melestarikan nilai-nilai lokal masyarakat ata ammatoa kecamatan Kajang kabupaten Bulukumba. Skripsi S1. Tidak DiterbitkanUniversitas Hasanuddin Makassar.

[17] Skripsi: Amiruddin, (2012). Kajian nilaipasang ri kajang tentang prinsip hidup tallasa kamasemase pasang ri kajang. Skripsi S1. Tidak Diterbitka. STKIP Bulukumba Muhammadiyah.

[18] Skripsi: Nurdiansah, (2014).Pemilihan dan peranan kepala Adat (ammatoa) dalam masyarakat hukum adat kajang.Skripsi S1. Tidak DiterbitkanUniversitas Hasanuddin Makassar.

[19] Skripsi: Jumarlin Muslim, (2014). Peranan Lembaga Adat Ammatoa Terhadap Kelestarian Hutan Produksi Terbatas Tana Toa Kajang. Skripsi S1. Tidak Diterbitkan Universitas Muhammadiyah Makassar. 